\title{
Jacek Moroz
}

Uniwersytet Szczeciński

\section{Czy relatywista może być parezjastą?}

Tytułowe pytanie nie powinno wywoływać zdziwienia, ponieważ relatywizm kojarzony bywa z względnością, wieloznacznością, a nawet nieuczciwością. Utożsamia się go niekiedy z postawą pozbawioną jakiegokolwiek "gruntu aksjologicznego", co powoduje, iż z łatwością relatywiście można przypisać anarchistyczny sposób myślenia i działania. Wobec powyższego, wszelkie apriorycznie pojmowane normy, wartości, kryteria i oceny to jedynie puste frazesy nieposiadające ani "mocy” normatywnej, ani też regulatywnej. Z takiej perspektywy sądom powinnościowym można przypisać jedynie funkcję performatywną, w niektórych zaś przypadkach wartość eksplanacyjną ${ }^{1}$. Nic poza tym. Czy wobec tego relatywista może być parezjastą? Uważam, że tytułowe pytanie jest w równym stopniu problematyczne, jak i zasadne, dlatego też moim celem będzie próba ujęcia tego zagadnienia z dwóch teoretycznie odmiennych pozycji - realisty i konstruktywisty epistemologicznego. Chociaż odpowiedź na powyższe pytanie wydawać się może niejednoznaczna, postaram się pokazać, iż z perspektywy wspomnianego realizmu faktycznie tego typu mariaż jest nie tylko niemożliwy, ale nawet nieetyczny. W końcowej części tekstu spróbuję jednak nakreślić możliwości godzenia postawy parezjasty z akceptacją dla stanowiska relatywistycznego. Mógłby ktoś oczywiście twierdzić, iż niczego zaskakującego nie ma w łączeniu obu stanowisk, jeśli bowiem zajmują one całkowicie odmienne „dziedziny ontyczne”, nie wchodząc ze sobą w kolizję, nie będą też generować sprzeczności. Taką konkluzję można zaakceptować w sytuacji, gdy oba poję-

Pozwalają bowiem wyjaśnić sposób czyjegoś myślenia i działania podejmowanego pod wpływem pełnej aprobaty dla danej wartości bądź zasady. 
cia - parezja i relatywizm - odnoszą się do zupełnie różnych stanowisk, nie tylko z uwagi na swoją treść, ale również „poziom oddziaływania”, wówczas to, nie będąc kontradyktorycznymi, „umożliwiają” relatywiście jednoczesne bycie parezjastą. Niemniej parezja nie jest etycznie obojętna, determinuje konieczność dysponowania określonym punktem odniesienia dla wygłaszanych przekonań. Dlatego też sporna staje się kwestia możliwości konsekwentnego godzenia postawy parezji z przekonaniem o słuszności relatywizmu. Wobec powyższego nie podejmę się udzielenia jednoznacznej odpowiedzi na tytułowe pytanie, wymagałoby to fundamentalnie osadzonych założeń i przyjęcia jednoznacznej postawy. Tego zrobić nie mogę.

\section{Relatywizm a parezja}

O relatywizmie można mówić na różne sposoby. Nie jest to stanowisko homogeniczne, co powoduje, że istnieje wiele jego ujęć i interpretacji. W SŁowniku WyRAzów OвCYCH definiowany jest jako „pogląd filozoficzny, według którego wartości logiczno-poznawcze (prawda, fałsz), etyczne (dobro, zło) i estetyczne oraz związane z nimi normy i oceny mają charakter względny"2. Etymologicznie nawiązuje w linii prostej do łacińskiego terminu relativus, co oznacza 'względny'. Stanowisko relatywizmu można przedstawić przy użyciu bardzo prostego schematu: $x$ jest relatywne do $y^{3}$, gdzie za zmienną $x$ podstawiamy wartości epistemiczne, etyczne lub estetyczne, a za $y$ między innymi czynniki historyczne, kulturowe, społeczne, językowe, psychologiczne. Mnogość czynników relatywizujących, jak i liczba przedmiotów poddających się relatywizacji powoduje, że z ogólnego stanowiska filozoficznego określanego mianem „relatywizmu” może wyłaniać się wiele różnorodnych form. Stąd podanie wyczerpującej typologii relatywizmu nie jest łatwe, acz konieczne dla lepszego zrozumienia, czym ten w istocie swej jest. Poniżej prezentuję jedną z możliwych klasyfikacji, będącej jedynie próbą uporządkowania omawianego tu zagadnienia:

„1. Relatywizm pojęciowy (ontologiczno-pojęciowy). Istnienie klasy obiektów O jest zależne od systemu pojęciowego S. System pojęciowy S1 będzie generował obiekty $\mathrm{O}_{1}$, analogicznie klasa obiektów $\mathrm{O}_{2}$ jest efektem obowiązywania systemu $\mathrm{S}_{2}$. Zgodnie z tym relatywizmem ontologia jest implikowana przez dany system pojęciowy. Jednocześnie przyjmuje się założenie o niewspółmierności systemów pojęciowych.

Słownik wyrazów obcych, E. Sobol (red.), PWN, Warszawa 1999, s. 954.

C. Swoyer, Relativism, [w:] Stanford Encyclopedia of Philosophy, w: http://plato.stanford. edu/entries/relativism/ [11.11.2013]. 
2. Relatywizm semantyczny. Istnieją takie języki $J_{1} \mathrm{i} \mathrm{J}_{2}$, że terminy i zdania języka $J_{1}$ nie mogą być wyartykułowane bez utraty znaczenia (całkowicie lub częściowo) w języku J.

3. Relatywizm epistemologiczny. Wszystkie rezultaty aktów poznawczych zależą od wyposażenia, usytuowania i stanu podmiotów poznania.

a) Relatywizm wiedzy. Wiedza zależy od różnorodnych czynników relatywizujących, między innymi epoki, kultury, gatunkowych predyspozycji, indywidualnej perspektywy. Relatywizm wiedzy to zatem pogląd, że nie istnieje wiedza o charakterze uniwersalnym czy niekontekstowym.

b) Relatywizm uzasadnienia. Pojęcie uzasadniania ${ }^{4}$ ściśle związane jest z pojęciem wiedzy. Obok sporów na temat zasadności relatywizmu wiedzy toczone są dyskusje o to, czy istnieją obiektywnie skuteczne sposoby dowodzenia i procedury uzasadniania twierdzeń. Zgodnie z poglądami relatywistów wszystkie zależne są od kontekstu, w którym powstały. Na kontekst składają się normy obowiązujące w danym czasie i miejscu, a nawet czynniki podmiotowe. Zatem różne społeczeństwa i kultury mają odmienne systemy uzasadniania swojej wiedzy i wszystkie one traktowane są przez relatywistów jako równoważne. Nie można więc powiedzieć, że któryś z systemów jest lepszy lub gorszy, nie istnieje obiektywny, uniwersalny sposób ich oceny.

c) Relatywizm prawdy. Prawdziwość danego sądu zależna jest od podmiotu, czasu i miejsca jego stwierdzania. Dwa sądy sprzeczne mogą być zarazem prawdziwe (na przykład dla różnych podmiotów).

4. Relatywizm etyczny. Wszystkie wartości moralne zależne są od przyjętego w danej kulturze/społeczeństwie/grupie systemu moralnego. Nie istnieją zatem uniwersalne wartości moralne.

5. Relatywizm estetyczny. Wszystkie wartości estetyczne zależne są od kultury/społeczeństwa/grupy społecznej. Nie istnieją zatem uniwersalne wartości estetyczne"6.

Stając na gruncie relatywizmu można zatem przyjąć, że nasz sposób postrzegania tego, co w szerokim sensie nazywamy rzeczywistością, jak również kryteria jej oceny w pełni są zależne od kontekstu (do którego należy

4 Termin „uzasadniać”, za R. Chisholmem, będę odnosić do oceny epistemicznej przekonań. Por. R. M. Chisholm, Teoria poznania, przekł. R. Ziemińska, Daimonion, Lublin 1994, s. 25. Ponadto, w stosunku do przekonań będę używał zamiennie terminów „uzasadnienie” i „racjonalność”, gdzie „racjonalne przekonania” to przekonania dobrze uzasadnione.

5 Por. M. Baghramian, Relativism, Routledge. Taylor \& Francis Grtoup e-Library, Londyn - Nowy Jork 2005, s. 116.

6 J. Moroz, Dyskusja z relatywizmem prawdy w Szkole Lwowsko-Warszawskiej, Scholar, Warszawa 2013, s. 20-21. 
również podmiot zdolny do generowania aktów poznawczych i wydawania sądów wartościujących). Z naszego punktu widzenia szczególnie interesujące są dwa aspekty relatywizmu: aletyczny - implikujący względność prawdy oraz etyczny. Pierwszy, z uwagi na nasze ograniczenia poznawcze, drugi, będący w pewnym sensie konsekwencją pierwszego, ze względu na uwikłanie moralne wszystkich relacji interpersonalnych (notabene ściśle powiązane z postawą parezjasty). W powyższym „wykazie” relatywizmów nie został uwzględniony jeszcze jeden, $\mathrm{z}$ naszego punktu widzenia również bardzo ważny, jego rodzaj. Jest to tak zwany relatywizm kulturowy. Można oczywiście zredukować go do relatywizmów wcześniej wymienionych, twierdząc, iż to wszystko, co wspomniany relatywizm za sobą pociąga jest już zawarte w relatywizmach wyżej wymienionych (między innymi pojęciowym, semantycznym, epistemologicznym, etycznym). Można się na to zgodzić, ponieważ w zasadniczo odmiennych kulturach (bo do nich ów relatywizm się zwykle odnosi) do opisu rzeczywistości używa się różnych języków, co skutkuje odmiennym postrzeganiem świata. Byłbym nawet zwolennikiem radykalnego stwierdzenia, że niektóre $\mathrm{z}$ tych języków (rozumianych tu jako układy pojęciowe) są niewspółmierne, co determinuje daleko idące konsekwencje natury ontologicznej. Oznaczałoby to, iż przedstawiciele dwóch odmiennych kultur, dysponujący dwoma całkowicie różnymi językami ${ }^{7}$, dokonując konceptualizacji otaczającej rzeczywistości, jednocześnie powołują do życia zupełnie odmienne światy. Zatem wszelkie zjawiska i procesy (społeczny, fizykalny czy metafizyczny) będą postrzegane przez pryzmat danej rzeczywistości kulturowej. W wyniku enkulturacji każdy z nas nabywa właściwych dla danej kultury „kompetencji poznawczej”, która w sposób zasadniczy rzutuje na posiadany punkt odniesienia dla wszelkich sądów wartościujących. Oznacza to, że wzrastanie i wychowanie w różnych kulturach w sposób zasadniczy wiąże się ze zrozumieniem i akceptacją (lub jej brakiem) dla systemu wyboru, uzasadniania i oceniania różnych kryteriów epistemicznych, moralnych czy estetycznych.

$\mathrm{Z}$ powyższych uwag na temat relatywizmu wyłania się jego fundamentalna cecha - kontekstualność. Dla relatywisty wszelkie wartości, w tym prawda, wiedza, dobro czy sprawiedliwość, zyskują znaczenie tylko w pewnym kontekście, będąc dodatkowo w pełni od niego uzależnionymi. Tak więc poza kontekstem sens tracą wszelkie wartości, a rzeczywistość przestaje właściwie istnieć. Czy relatywista może być zatem parezjastą? Związki parezji

Niewspółmierne języki generują problem przekładu jednego języka na drugi, a w konsekwencji problem komunikacji pomiędzy obiema kulturami. 
z relatywizmem są niejednoznaczne. Pojęcie „parezji”, rodowód którego sięga starożytności, wywodzi się od słowa parrhesiazesthai, co oznacza 'powiedzieć wszystko'. Zatem parezjastą można nazwać każdego, kto niczego nie ukrywa, mówi to, co ma na myśli, a co warte jest powiedzenia. Parezja jest swego rodzaju relacją pomiędzy mówiącym a tym, co wypowiedziane. Jednakże, co trzeba wyraźnie zaakcentować, wspomniana relacja jest nacechowana uczciwością, co w praktyce oznacza, że mówiący z przekonaniem, bezpośrednio i, co najważniejsze, szczerze, wyraża swoją opinię na dany temat. Tym bardziej nie używa on żadnych chwytów retorycznych ani też sofistycznych kamuflaży, by myśl swą chytrze przemycić 8 . Innymi słowy, bycie parezjastą to obowiązek (uwewnętrzniony, a nie narzucony z zewnątrz) mówienia prawdy lub po prostu, ujmowanie rzeczy takimi, jakimi są, bądź (jak powiedziałby ostrożniejszy parezjasta), jakimi się nam przedstawiają. Mam świadomość, iż powyższemu opisowi parezji do zupełności wiele brakuje9 ${ }^{9}$. Jednak na użytek naszego wywodu przytoczona charakterystyka wydaje się być wystarczającą. Nie zamierzam tu ani interpretować starożytnego czy foucaultowskiego rozumienia parezji, ani też z nimi polemizować. Przyjmuję, że o parezji można myśleć w kategoriach prawdomówności, mimo iż intensja tego pierwszego jest szersza. Partezjasta, jak go rozumiem, będzie funkcjonował w obrębie takiego tylko dyskursu, w którym brak wszelkich zafałszowań rzeczywistości, dającej się zakomunikować rozmówcy.

\section{Pomiędzy dyskursem a prawdą}

Jestem zdania, że nie można, choćby nie wiem jak, próbować zająć pozycji poznawczej, sytuującej się poza jakimkolwiek dyskursem. Zawsze, wydając dowolne sądy, oparte na dowolnych spostrzeżeniach bądź obserwacjach, czynimy to z konkretnego punktu widzenia. Ten ostatni, niezależnie od użytego terminu czy nazwy („perspektywa poznawcza”, „język”, „paradygmat”, „dyskurs” lub po prostu „kontekst poznawczy”), stanowi konglomerat znaków wchodzących ze sobą w określone i ustalone na drodze konwencji relacje, tworząc system komunikacyjny (język). Ów konstrukt językowy konstytuuje pewną perspektywę ontologiczną ,niewidoczną z innych pozycji”. Takich systemów może być wiele, a każdy z nich tworzy swoisty świat. Niemniej, należy uściślić kwestię relacji języka do „rzeczywistości”. Mówiąc o języku,

8 M. Foucault, Discourse and Truth: the Problematization of Parrhesia. 6 lectures given by Michel Foucault at the University of California at Berkeley, Oct-Nov. 1983, http://foucault. info/system/files/pdf/DiscourseAndTruth_MichelFoucault_1983_o.pdf [22.11.2013].

9 Szczegółową analizą pojęcia i zarazem zjawiska parezji zajmował się Michael Foucault w swym Discourse and Truth. Por. M. Foucault, Discourse and Truth... 
nie mam na myśli systemu znaków języka etnicznego (polskiego, angielskiego $\mathrm{i}$ innych), ten bowiem nie generuje żadnego istotnego, z naszego punktu widzenia, problemu. Sytuacji, w której dwa systemy pojęciowe są wzajemnie nieprzekładalne nie wyklucza posługiwanie się tym samym językiem etnicznym, wyklucza natomiast możliwości ich wzajemnego przekładu. Twierdzę, iż kontekst językowy konstytuuje kontekst poznawczy, czego doskonałym przykładem jest - z naszej kulturowo zdeterminowanej perspektywy - dosyć prymitywna forma życia plemienia Azande, opisana przez Evansa-Pritcharda ${ }^{10}$.

Azande wierzą, że niektórzy ludzie są czarownikami [witches] i mogą mocą wrodzonej właściwości wyrządzić im krzywdę, czarownik nie odprawia żadnych obrzędów, nie wypowiada zaklęć i nie posiada leków. Akt czarów jest aktem psychicznym. Azande wierzą także, że czarnoksiężnicy [sorcerers] mogą sprowadzić na nich chorobę przez odprawianie magicznych obrzędów z ze złymi lekami. Azande wyraźnie odróżniają czarowników i czarnoksiężników. Przeciwko jednymi drugim wszakże posługują się wróżbitami, wyroczniami i lekami ${ }^{11}$.

Wiara w czary stanowi rdzeń światopoglądu Azande, pozwala im na zrozumienie i wyjaśnianie wielu zjawisk, z którymi na co dzień mają do czynienia. Jak pisze Evans-Pritchard:

...pojęcie czarów zaopatruje ich w filozofię naturalną, dzięki której relacje między ludźmi a nieszczęśliwymi wypadkami zyskują wyjaśnienie, oraz w gotowe i stereotypowe sposoby reagowania na tego rodzaju wypadki. Wiara w czary obejmuje również system wartości, który reguluje postępowanie ludzi ${ }^{12}$.

Czary w życiu Azande nie są jedynie dodatkiem, ale są wszechobecne, wchodząc w skład dobrze rozpoznanej i „praktykowanej” ontologii. Wiara w czary, wyrocznie i magię, może wydawać się nieco zaskakująca i mało wiarygodna, jednak Azande kierują się swoistą logiką rozumowania, która, jak zauważa sam Evans-Pritchard, regulując ich życie społeczne zasadniczo nie odbiega od logiki regulującej sposoby funkcjonowania społeczeństw zachodnich. Ta rewolucyjna, jak na owe czasy, myśl Evansa-Pritcharda może prowadzić do tezy, że nasz sposób postrzegania rzeczywistości, wraz z tym, co nazywamy racjonalnością naukową, jest tylko jednym z wielu możliwych, a do tego równorzędnych, sposobów ujmowania rzeczywistości doświadcza-

\footnotetext{
10 E. Evans-Pritchard, Czary, wyrocznie i magia u Azande. Wersja skrócona, przekł. S. Szymański, PIW, Warszawa 2008.

11 Ibidem, s. 23.

12 Ibidem, s. 37.
} 
nej ${ }^{13}$. Oczywiście, samo pojęcie „logiki” funkcjonować może jedynie w określonym systemie pojęciowym i niemożliwe jest, by stwierdzić, że „logika myślenia i działania" dwu różnych społeczeństw jest identyczna lub nawet zbliżona. Pojawia się zatem problem przekładu tekstu z jednego języka na inny, czyli: problem interpretacji samej rzeczywistości.

Można jednak powiedzieć, iż przykład religijnych praktyk bądź „subtelnego rozumienia” otaczającej rzeczywistości jest nieco wyszukany, a przez to właśnie niedający się jednoznacznie zinterpretować i opisać. Niemniej, istnieją proste doświadczenia i sytuacje, w pełni poddające się „translatorskim zabiegom". Do takich miałyby należeć codzienne i całkiem prozaiczne przypadki, w których określone „empiryczne dowody” dobitnie świadczą o możliwości ich pełnego uchwycenia, zrozumienia, opisania, a jednocześnie przełożenia na różne języki. Niestety, zagadnienie wzajemnego przekładu języków odkrywa, jak wykazał William van Orman Quine ${ }^{14}$, szereg istotnych problemów. Wyobraźmy sobie biegnącego po polanie królika i dwójkę obserwatorów tej, z pozoru bardzo trywialnej, sytuacji. Dodajmy, że pierwszy to badacz lingwista, chcący poznać język i zwyczaje plemienia dotąd nieskażonego kontaktem ze „światem zachodnim”, zaś drugi to tubylec, posługujący się nieznanym językiem. Problem z przekładem jest tym większy, że nie wiemy zupełnie niczego o tych ludziach i ich zachowaniach. Nie istnieją żadne podręczniki przekładu, ich zachowania oraz sposoby postrzegania otoczenia mogą znacząco różnić się od naszych. W tej sytuacji można zdać się jedynie na obserwację elementarnych zachowań werbalnych, wjak najmniej skomplikowanych warunkach. A zatem załóżmy, że przebiegający królik wywołuje następującą reakcję werbalną - Gavagai. W tej sytuacji lingwista może domyślać się, że reakcja wywołana jest pojawieniem się zwierzęcia. Niemniej, nie jest pewne czy Gavagai oznacza królika, jego i otoczenie, w którym się znajduje, powszechnik, którego jednostkowy królik jest egzemplifikacją, rodzaj poży-

13 Nie jest to teza, którą Evans-Pritchard w pełni by zaakceptował, ponieważ w cytowanej pracy wygłasza on szereg sądów oceniających przyjmując a priori obiektywistyczny punkt widzenia. Wskazuje na to Peter Winch, cytując liczne przykłady wypowiedzi antropologa w stylu: „czarownicy, oczywiście, nie istnieją”, lub uwag podkreślających „bezsens”, na którym opiera się życie Azande. Por. P. Winch, Rozumienie społeczeństwa pierwotnego, [w:] Racjonalność i styl myślenia, wyb. i oprac. E. Mokrzycki, Wyd. IFiS PAN, Warszawa 1992, s. 243. Antropolog wydaje się więc zakładać, że istnieje jakaś wspólna wszystkim kulturom płaszczyzna, niezależnie od ich odmienności, na bazie której można formułować kryteria i dokonywać ocen zastanej, kulturowo uwarunkowanej „rzeczywistości”. Takie podejście wydaje się, co najmniej, problematyczne.

14 Koncepcję „radykalnego przekładu” i tezę o niezdeterminowaniu przekładu Quine rozwija w artykule Przekład i znaczenie. Por. W. V. O. Quine, Przekład i znaczenie, [w:] idem, Słowo i przedmiot, przekł. C. Cieśliński, Fundacja Aletheia, Warszawa 1999, s. 39-96. 
wienia, a może jeszcze coś, o czym nasz lingwista (z racji odmienności kulturowej) nie może mieć nawet pojęcia. Ten przykład, bez wchodzenia w subtelności Quainowskiej filozofii, wystarczy, by zilustrować jak dalece skomplikowane jest dokonanie tak zwanego radykalnego przekładu, nawet w przypadku „nieskomplikowanych sytuacji empirycznych”. Na tej podstawie Quine wysunął tezę o niezdeterminowaniu przekładu, które powoduje, że lingwista nie tylko styka się z niezdeterminowaniem znaczenia, ale również odniesienia przedmiotowego. Dzieje się tak dlatego, że przekład poszczególnych wyrażeń zależy od przekładu innych wyrażeń, może więc istnieć wiele przekładów stojących w zgodzie z dostępnymi świadectwami empirycznymi. Taka sytuacja stwarza doskonałe podwaliny pod relatywizm ontologiczny. Nie pomoże tu nawet definicja ostensywna, ponieważ badacz nie może wniknąć w analizowaną kulturę bez znajomości języka, ten zaś poza kulturą pozbawiony jest znaczenia.

Realizm wewnętrzny Hilarego Putnama dostarcza niezwykle sugestywnego obrazu rzeczywistości widzianej „od wewnątrz”. Świat można opisywać na różne sposoby, ponieważ sam w sobie nie posiada on, nawet z „ekstraobiektywnej” boskiej perspektywy, żadnej określonej struktury. Zatem to, co „światem” nazywamy może być ustrukturyzowane na wiele różnych, a zarazem równoważnych ${ }^{15}$ sposobów. Nie ma lepszej lub gorszej perspektywy, a co za tym stoi - lepszego lub gorszego dostępu do rzeczywistości. Pojęcie „rzeczywistości samej w sobie”, funkcjonując wyłącznie w określonym języku (jeśli ten w ogóle je uwzględnia), traci swój absolutny i pozakontekstowy sens. Problem tkwi jednak w tym, że wykazujemy skłonność do tego, by modele językowe traktować jako niezależne od jakiegokolwiek opisu. I choć w rozumienie języka wkomponowane jest odniesienie przedmiotowe terminów, to jednak - jak pisze Putnam ${ }^{16}$ - zawsze należy wziąć pod uwagę określony kontekst zastosowania. Przyczynowe teorie odniesienia nie dostarczają tutaj żadnych dodatkowych możliwości, gdyż, zdaniem filozofa, opierają się one na ślepej wierze w to, że świat sam wyznaczy „właściwą” ekstensję każdego terminu ${ }^{17}$. Putnam nie pozostawia złudzeń: „Świat [...] nie zajmuje się wyróżnianiem modeli ani interpretowaniem języków. To my interpretu-

15 Chodzi o takie rozumienie pojęcia „równoważności”, które funkcjonuje w naszym języku. Nie można bowiem zakładać, zgodnie z wcześniejszymi ustaleniami, że jakiemukolwiek terminowi językowemu przysługuje jakiś „specjalny” interlingwistyczny charakter.

16 Patrz: H. Putnam, Modele i rzeczywistość, [w:] idem, Wiele twarzy realizmu i inne eseje, PWN, Warszawa 1998, s. 222.

${ }_{17}$ Por. ibidem, s. 223. 
jemy nasze języki, i nikt inny, ani nic innego tego nie robi"18. W tej sytuacji rozsądną alternatywą jest przyjęcie semantyki antyrealistycznej. Podobnie Richard Rorty, odnosząc się z akceptacją dla holistycznej koncepcji Quine’a, stwierdza, iż wypływa ona „...z przeświadczenia, że uzasadnienie nie jest sprawą jakiejś szczególnej relacji między ideami (czy słowami) a przedmiotami, ale sprawą wymiany poglądów, rzeczą praktyki społecznej”"19. To funkcjonowanie instytucji społecznej, jako kryterium uzasadniania przekonań, pozwala na prawidłowe rozumienie "poznania”. W takim ujęciu nie ma ani potrzeby, ani sensu dopatrywania się „trafności przekonań” zależnych od czegoś zewnętrznego. Konfrontacja zostaje zastąpiona przez konwersacje, a „umysł” traci swój uprzywilejowany status „Zwierciadła natury”20.

Zadaniem powyższych odniesień i przykładów nie jest jakieś ostateczne dowodzenie słuszności czy zasadności relatywistycznego spojrzenia na rzeczywistość. Miały one jedynie ogólnie nakreślić i zobrazować bogatą teoretyczną perspektywę pluralizmu aksjologicznego, a zarazem poznawczego. Akceptacja dla tego typu pluralizmów nie jest jednoczesną deklaracją rezygnacji z racjonalnych kryteriów oceny sytuacji. Jest to jedynie przyznanie się do lokalności, a tym samym ograniczoności obowiązywania uznawanych przez nas - epistemicznych, etycznych, estetycznych - wartości, zasad i kryteriów.

\section{Relatywista czy parezjasta?}

Relatywizm jest stanowiskiem specyficznym, wielu uważa, że jego główna teza prowadzi do samozniesienia. Niemniej, od czasów greckich sofistów, relatywizm znajduje swoich zagorzałych protagonistów i nic nie wskazuje na to, aby zarzut z samozniesienia miał zakończyć jego wielowiekową karierę. Wydaje się, że nie tylko nie grozi mu logiczne, a w konsekwencji filozoficzne unicestwienie, lecz wręcz przeciwnie, coraz częściej okazuje się być postrzegany jako jedyna możliwa alternatywa dla absolutyzmu i uniwersalizmu. Jednak czy parezjasta, będąc w pełni świadomym i konsekwentnym relatywistą, może, z pełnym przekonaniem, oczekując zrozumienia i adekwatnej reakcji, wygłaszać swoje poglądy?

$\mathrm{Na}$ poziomie psychologicznym być może tak, ale czy nie popadnie w sprzeczność logiczną? Przyjmijmy, że nasz parezjasta-relatywista zajmuje stanowisko skrajne, ale zarazem spójne. Zakładając, że świat jest amorficzny

\footnotetext{
18 Ibidem, s. 223.

19 R. Rorty, Filozofia a zwierciadło natury, przekł. M. Szczubiałka, Wyd. Spacja: Fundacja Aletheia, Warszawa 1994, s. 153.

20 Ibidem, s. 153.
} 
(w sobie nie mając formy i kształtu), zdaje sprawę z względności i równoważności wielu możliwych opisów rzeczywistości niemogących rościć prawa do słuszności czy jedyności. Ponadto owa wielość może generować różne koncepcje prawdziwości. Relatywista, projektując warunki weryfikacji i oceny twierdzeń i teorii naukowych ${ }^{21}$, świadomie rezygnuje z potężnego narzędzia metafizyki - „rzeczywistości samej w sobie”, obdarzonej uniwersalną mocą uprawdziwiania $^{22}$, a zarazem uprawomocniania wybranej klasy sądów. Owa rzeczywistość „powodowałaby”, że w wyniku zachodzenia, pomiędzy nią a światem, relacji korespondencji ${ }^{23}$, niektóre $\mathrm{z}$ wydawanych przez nas sądów byłyby prawdziwe, inne zaś nie. $Z$ punktu widzenia realisty relacja tego typu jest kwestią zasadniczą, albowiem „wyróżniając” pewną klasę zdań sprawia, iż ich prawdziwość nie jest już zależna od przygodnych sytuacji, lokalnie ustalonych i respektowanych konwencji albo też warunku spójności czy użyteczności. Sąd (zdanie, twierdzenie) jest prawdziwy ${ }^{24}$ lub nie, zależnie od zachodzenia wspomnianej relacji odpowiedniości bądź jej braku i nic nie jest w stanie tego zmienić. Przyjmując taką perspektywę, można bez przeszkód głosić swe przekonania, słusznie zakładając, iż stosując rzetelną metodę poznania, dochodzi się do twierdzeń prawdziwych bądź takich, które są „prawdzie najbliższe”. Błąd jest czymś naturalnym, niemniej jednak, świadomość istnienia czegoś realnego, czegoś, co dla wydawanych sądów stanowi „archimedesowy punkt oparcia”, pozwala do prawdy się przybliżać, a w niektórych przypadkach nawet ją osiągać. Wyposażony w taką teorię parezjasta może bez przeszkód wygłaszać swoje poglądy i bronić stanowiska, wierząc zarazem, że ma ono swoje oparcie w czymś od nas niezależnym, obiektywnym, czymś, co nie jest tylko kwestią zajmowanej perspektywy, ale, co - przypominając kantowską ideę regulatywną - może stanowić rzeczywiście sedno intelektualnej aktywności będąc tym, o co można i warto walczyć. Jest to zatem postawa o tyle metafizyczna, co etyczna. Jest to również wiara w słuszność i zasadność swoich przekonań, wiara, z którą parezjasta bez przeszkód może realizować swój obowiązek mówienia prawdy...

${ }^{21}$ Powołując się przy tym na kryterium pragmatyczne, koherencji lub jakiekolwiek inne.

22 Odwołuję się tutaj do filozoficznego założenia, a zarazem wiary w to, iż pewne sądy (ang. proposition), będąc właściwymi nośnikami prawdziwości (ang. truthbearer), zyskują wartość logiczną dzięki istnieniu tzw. dziedziny przedmiotowej (rzeczywistości lub świata samego w sobie), uprawdziwiającej wspomniane sądy (ang. truthmaker).

${ }_{23}$ Pomijam tu wielce problematyczną kwestię niekryterialności klasycznej koncepcji prawdy.

${ }^{24}$ W takim ujęciu prawdziwość jest własnością, która przysługuje sądowi zawsze albo nigdy, będąc jego cechą odwieczną. 
W tym miejscu należy zapytać o możliwość wypełnienia zobowiązań etycznych prezjasty-relatywisty. Trzeba pamiętać, iż relatywista może wyrażać swe przekonania jednocześnie zdając sobie sprawę $\mathrm{z}$ tego, iż jego sądy mają zasięg tylko lokalny - obowiązują jedynie w obrębie danego paradygmatu bądź modelu. Problem polega na tym, że parezjasta niejako przyjmuje na siebie obowiązek mówienia tego, co uznaje nie tylko za słuszne, ale również uzasadnione $\mathrm{i}$ istotne $\mathrm{w}$ jakimś ważnym sensie; jest to swego rodzaju odpowiedzialność, polegająca na byciu uczciwym względem tych, z którymi wchodzi się w różnorakie relacje. Wobec powyższego, przekonania parezjasty obligują go do określonego i skutecznego, choćby na poziomie komunikacyjnym, działania. Czy zatem można pozostać parezjastą w zetknięciu z odmiennością przekonań naukowych wynikłych z uznawania niewspółmiernych paradygmatów, różnorodności kulturowej lub/i sprzeczności przekonań moralnych? Problem parezjasty-relatywisty pojawia się wówczas, gdy założenie o istnieniu wielości niewspółmiernych modeli rzeczywistości implikuje możliwość braku skutecznej komunikacji osób kulturowo zakorzenionych w odmiennych modelach. Parezjasta nie zostanie wówczas odpowiednio (bądź nawet wcale) zrozumiany. Można jednak powiedzieć, iż za tę sytuację w żaden sposób odpowiedzialności nie ponosi, bo choć miał intencje słuszne, różnic kulturowych nie przeskoczy. Co jednak w sytuacji odmiennych systemów etycznych funkcjonujących w świadomości i praktyce społeczeństwa, w którym żyjemy? Co w przypadku jawnie krzywdzących, z punktu widzenia parezjasty, rozstrzygnięć natury moralnej? Nie ma już bariery ontologiczno-pojęciowej, a powinnością parezjasty jest zajęcie stanowiska. Stanowiska, które będzie wyrazem sprzeciwu wobec zaistniałej niegodziwości, wyrządzanemu złu! W odpowiedzi (i być może proteście) na te ostatnie parezjasta-relatywista nie może powołać się na uniwersalne wartości moralne ${ }^{25}$, nie może również dowodzić swych racji w oparciu o jakieś obiektywnie istniejące, a przeto powszechnie akceptowane i skuteczne sposoby dowodzenia lub procedury uzasadniania swoich twierdzeń ${ }^{26}$. A zatem w obronie swych racji nie powoła się na żadne uniwersalne kryterium, mogąc mówić jedynie o swoich racjach i przekonaniach. Tym samym wysoce prawdopodobne jest, że ze swoimi argumentami i racjami dotrze jedynie do tych, z którymi zgadza się, co do podstawowych wartości moralnych. Nie to jednak, wydaje się, najważniejsze i nie to jest głównym argumentem uzasadniającym postawioną w artykule tezę. Parezjasta, uznając twierdzenie, że cała rzeczywistość

25 Por. relatywizm etyczny.

26 Por. relatywizm uzasadnienia. 
(w tym wartości: epistemiczne, etyczne) jest niczym innym, jak tylko rodzajem konstruktu społeczno-kulturowego, konsekwentnie musi zaaprobować założenia i następstwa relatywizmu (między innymi pojęciowego, poznawczego i etycznego). Oznacza to, iż nie istnieją, o czym wielokrotnie była już mowa, żadne absolutne ani uniwersalne standardy orzekania o tym, które z poglądów, stanowisk czy teorii jest lepsze, bardziej racjonalne czy wartościowsze. Czy wiedząc to wszystko parezjasta-relatywista wciąż będzie mógł uczciwie i z poczuciem słuszności głosić i bronić swych poglądów? Wydaje się, że nie.

We wstępie do niniejszego artykułu stwierdziłem, że nie mogę przyjąć jednoznacznej postawy. Należy jednak podkreślić, iż powyższą krytykę można utrzymać z jednej strony narzucając pojęciu „parezja” dość restrykcyjne wymagania, $z$ drugiej zaś przyjmując perspektywę nie relatywisty, lecz realisty metafizycznego, a zarazem aletycznego absolutysty (są to "mocne” metafizyczne supozycje). Jako konsekwentny i racjonalnie ${ }^{27}$ zorientowany relatywista - co na pierwszy rzut oka może zabrzmieć nieco paradoksalnie - nie przyjmę na siebie tych wszystkich zobowiązań metafizycznych, które, z punktu widzenia realisty epistemologicznego, wydają się być koniecznymi dla obrony parezji. Niemniej, pojęciu „parezji” mogę nadać psychologiczną interpretację, pozbawioną konotacji, a zarazem zobowiązań ontologicznych. Wówczas nie oceniam innych stanowisk z punktu widzenia absolutnie pojętych własności naszych sądów i uniwersalnych wartości. Liczę się z tym, iż niekiedy nie będę zrozumiany i sam nie pojmę sposobu myślenia i działania innych ludzi. Wiem również dobrze, że w niektórych przypadkach nie przekonam, a być może nawet nie mam prawa przekonywać, do swoich poglądów. W tej sytuacji pozostaje mi akceptacja dla czegoś w rodzaju kulturocentryzmu Richarda Rorty'ego i racjonalności ograniczonej do danego kręgu ontyczno-semantycznego, nic więcej. Postulat negacji uniwersalności w połączeniu z odrzuceniem prawdy "egzystującej na zewnątrz”, a więc poza i w oderwaniu od ludzkiego umysłu, stwarza doskonałe warunki dla zrozumienia i przyjęcia tezy o zależności opisu świata (nie samego świata, o tym bowiem nic nie wiemy) od ludzkiej (nie jednostkowej lecz w szerszym bądź węższym zakresie zbiorowym) aktywności intelektualnej ${ }^{28}$. Nie można zatem stwierdzić, kto ma rację - społeczność Azande czy współczesny Europejczyk? Przejście z jednej gry językowej do drugiej (jeśli jest to w ogóle moż-

${ }^{27}$ Mam tu na myśli racjonalność ograniczoną do danego układu pojęciowego i związanych z nim praktyk społecznych.

${ }_{28}$ R. Rorty, Przygodność, ironia, i solidarność, przekł. W. J. Popowski, W.A.B., Warszawa 2009, S. 23-24. 
liwe) zmienia perspektywę wraz z kryteriami oceny. Nie znaczy to jednak, iż nic nie można zrobić, można wyrażać opinię, można też protestować, a nawet działać w zgodzie z parezjańskim przekonaniem o słuszności podejmowanych decyzji. Nie można jednak oczekiwać zrozumienia i akceptacji. Trzeba wiedzieć, iż jest to nasza ocena, nasza decyzja i nasza odpowiedzialność.

\section{BIBLIOGRAFIA}

Baghramian M., Relativism, Routledge, Taylor \& Francis Grtoup e-Library, Londyn - Nowy Jork 2005.

Chisholm R. M., Teoria poznania, przekł. R. Ziemińska, Daimonion, Lublin 1994.

Evans-Pritchard E., Czary, wyrocznie i magia u Azande. Wersja skrócona, przekł. S. Szymański, PIW, Warszawa 2008.

Foucault M., Discourse and Truth: the Problematization of Parrhesia. 6 lectures given by Michel Foucault at the University of California at Berkeley, Oct-Nov. 1983, http://foucault.info/system/files/pdf/DiscourseAndTruth_MichelFoucault_1983_o.pdf [22.11.2013].

Moroz J., Dyskusja z relatywizmem prawdy w Szkole Lwowsko-Warszawskiej, Scholar, Warszawa 2013.

Putnam H., Modele i rzeczywistość, [w:] idem, Wiele twarzy realizmu i inne eseje, przekł. A. Grobler, PWN, Warszawa 1998.

Quine W. V. O., Przekład i znaczenie, [w:] idem, Słowo i przedmiot, przekł. C. Cieśliński, Fundacja Aletheia, Warszawa 1999.

Rorty R., Filozofia a zwierciadło natury, przekł. M. Szczubiałka, Wyd. Spacja: Fundacja Aletheia, Warszawa 1994.

Rorty R., Przygodność, ironia, i solidarność, przekł. W. J. Popowski, W.A.B. Warszawa 2009.

Swoyer C., Relativism, [w:] Stanford Encyclopedia of Philosophy, http://plato.stanford.edu/entries/relativism/ [11.11.2013].

Winch P., Rozumienie społeczeństwa pierwotnego, [w:] Racjonalność i styl myślenia, oprac. E. Mokrzycki, Wyd. IFiS PAN, Warszawa 1992.

\section{Can a relativist be a parrhesiast?}

\section{SUMMARY}

The article aspires to provide the reader with the answer to the relevant question whether a relativist can be a parrhesiast. This is a complicated question, because parrhesia implies ethical commitment, which from the relative point of view is difficult to justify. I present two different philosophical perspectives (epistemological realism and radical relativism) as two possible approaches to the main problem.

KEYWORDS: relativism, parrhesia, epistemological realism. 